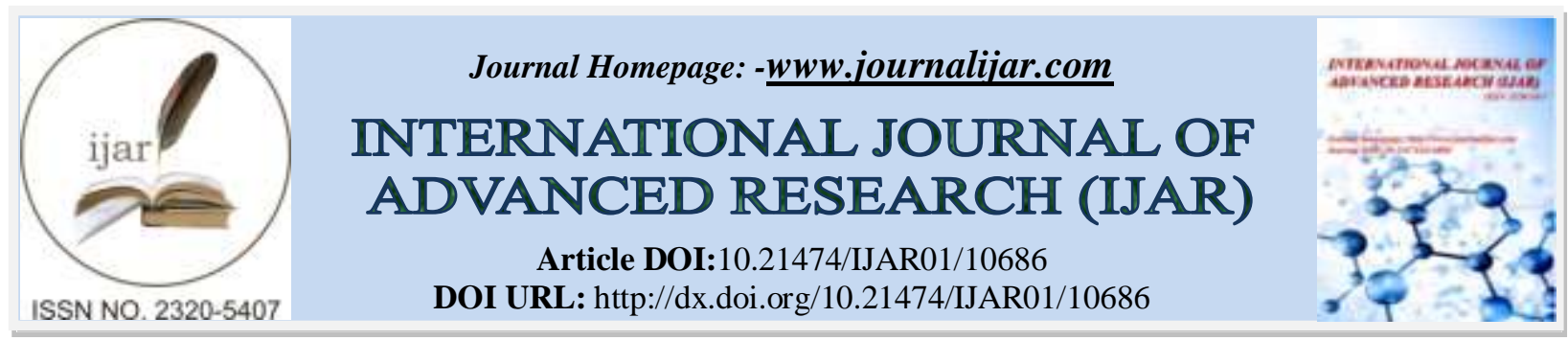

\title{
RESEARCH ARTICLE \\ ORGANISING IN THE STATE OWNED ENTERPRISE OF MIZORAM
}

\author{
Dr. Lalbiakzuali \\ Associate Professor, Department of CommerceGovernment Hrangbana College (Affiliated to Mizoram University), \\ Aizawl, Mizoram.
}

\section{Manuscript Info \\ Manuscript History \\ Received: 17 January 2020 \\ Final Accepted: 20 February 2020 \\ Published: March 2020 \\ Key words:- \\ Organising, State Owned Enterprises, \\ Managerial Skills, Work Environment}

\begin{abstract}
Organising is the identification and classification of required activities, the grouping of activities necessary to attain objectives, the assignment of each grouping to a manager with the authority necessary to supervise it, and the provision for coordination horizontally and vertically in the organisation structure. The management gurus have persistently laid out the importance of organising, the impact of managerial abilities and skills cannot be understated. Perhapstheremedytothe problems faced by State Owned Enterprises(SOEs) lies not in the financial freedom but the managerial abilities and skills. An attempt is made on the organising function of the state owned enterprises in the state of Mizoram, to explore the practices and the organisational behaviour in the context of prevailing work environment in their organisations, and identify the problem areas that has ailed its performance.
\end{abstract}

Copy Right, IJAR, 2020,. All rights reserved.

\section{Introduction:-}

Organising is the identification and classification of required activities, the grouping of activities necessary to attain objectives, the assignment of each grouping to a manager with the authority (delegation) necessary to supervise it, and the provision for coordination horizontally and vertically in the organisation structure. Organisations are the grand strategies created to bring order out of chaos when people work together, it sets the relationship among people, work and resources (Davis, 1983).

Mizoram lies in the border-tip of India's North-east. It is one of the most industrially backward States in the country. The Government of Mizoram through its industrial policies identified agro-based industries, handloom and handicraft industries, sericulture industries, electronic industries, village and cottage industries and selected consumer industries as priority industries to be developed in the State. Consistent with this, the Government of Mizoram set up five SOEs which are government companies registered under the Companies Act, 1956. They are:

1. Zoram Industrial Development Corporation Limited (ZIDCO)

2. Mizoram Handlooms and Handicrafts Corporation Limited (ZOHANDCO)

3. Mizoram Food and Allied Industries Corporation Limited (MIFCO)

4. Zoram Electronics Development Corporation Limited (ZENICS)

5. Mizoram Agriculture Marketing Corporation Limited (MAMCO)

However, these SOEs have failed to achieve the objectives for which they have been incorporated. Recommendation for improvement of performance or closure of the enterprises has been given by the Comptroller and Auditor General of India (CAG) in the year 2000 and again in 2005. The SOEs suffer from poor managerial efficiency 
which has an adverse impact on the financial and operational performance.Perhapstheremedytothe problems faced by the State Owned Enterprises(SOEs) in general and that owned by the Government of Mizoram lies not so much in it having financial freedom but the managerial abilities and skills. The organisation has to focus on the available resources, utilising them for achieving higher levels of productivity.

\section{Literature Review:-}

There are quite a number of studies conducted on the central public enterprises but very few are dedicated to the state level enterprises. In the process of this study, related literature on public enterprises as well as management has been reviewed in brief.

Ramanadham (1984) writes on the nature of public enterprise, comprising three studies. The first deals with what is to be expected of public enterprise by virtue of its conceptual significance. The second study explores the distinctive problems of public enterprise in developing countries and the third study looks into the important aspect of governmental relationships with public enterprise, namely controls, which have a determinative impact on its performance.

Saraswathy Rao (1986) attempts to present a panorama of different aspects of State Level Public Enterprises, particularly in Andhra Pradesh. The book consists of 15 chapters divided into five sections, each dealing with one broad area. The book adds to understanding of the working the SLPEs in the State.

Glynn (1987) distinguishes three categories of public sector accountability namely political accountability, managerial accountability and legal accountability.

Mishra et al (1989) present a macro analysis of State Level Public Enterprises (SLPEs) in 24 States of India, and outline policy implications for the control systems and management to upgrade the performance of these enterprises. The book is an outcome of the research conducted by the Institute of Public Enterprise (IPE) at the instance of the Planning Commission to develop a much needed database for the SLPEs.

Bhatia, B.S. and Batra, G.S. (2000) highlight some studies on the restructuring of public enterprises from international perspective and the Indian perspective covering the CPSUs and SLPEs. The book is an attempt to highlight the issues in management of public enterprises with special reference to privatisation and restructuring strategies.

Mishra and Kiranmai (2007) attempt to study the working of the State level public enterprises in Sikkim with a point of view to judge their suitability for the retention, closure and privatisation in the portfolio of the State.

Ganesh (2010) in his study on the SLPEs analyses their performance and prospects. A state-wise analysis of the SLPES relating to the 28 states including Mizoram has been prepared but the figures used for the Mizoram state owned enterprises was rather sketchy.

\section{Objectives:-}

This article focus on the organising function of the state owned enterprises, to explore the practices and the organisational behaviour in the context of prevailing work environment in their organisations.

\section{Research Methodology:-}

Scope of study: The study covers all the five state owned enterprises in the state of Mizoram, namely,

1. Zoram Industrial Development Corporation Limited (ZIDCO)

2. Mizoram Handlooms and Handicrafts Corporation Limited (ZOHANDCO)

3. Mizoram Food and Allied Industries Corporation Limited (MIFCO)

4. Zoram Electronics Development Corporation Limited (ZENICS)

5. Mizoram Agriculture Marketing Corporation Limited (MAMCO) 


\section{Data Sources:}

The study is based on primary as well as secondary sources of information. First, an intensive review of literature was undertaken to familiarise with the various aspects of the public sector philosophy and management, to identify the research problem, to evolve appropriate methodology and to formulate a conceptualframework for the study.

The study used structured schedules and direct interviews to solicit the primary information from the Board of Directors, top and middle level management. Further, an employee attitudinal survey was conducted to know the employees'attitudesinthecontext of their work environment.

\section{Results and Discussion:-}

The Structural Framework of the SOEs :

The five enterprises under the study are registered as government companies under the Indian Companies Act, 1956; a private limited company wholly owned by the government with no public equity participation, the share capital being solely contributed by the state government with the exception of ZIDCO, which is a joint venture of the Government of Mizoram and the Industrial Development Bank of India (IDBI) which is now taken up by the State Industrial Development Bank of India (SIDBI) in the ratio of 51:49. The shareholders are representatives of the Government of Mizoram with the maximum amount being held by the Chief Secretary and one share each alloted to the Secretary of the Finance department and the Secretary and Director of the concerned department. Table 1 shows the Departments under whose administrative control the SOEs fall in Government of Mizoram.

Table 1:- SOEs in Mizoram and their respective departments.

\begin{tabular}{|l|l|l|l|}
\hline Sl. & SOEs & Year Established & Department \\
\hline 1. & ZIDCO & 1978 & Industries \\
\hline 2. & ZOHANDCO & 1988 & Industries \\
\hline 3. & MIFCO & 1989 & Industries \\
\hline 4. & ZENICS & 1991 & $\begin{array}{l}\text { Industries ( 1991-2009) } \\
\text { Information \& Communication Technology(From 2009) }\end{array}$ \\
\hline 5. & MAMCO & 1993 & Trade \& Commerce \\
\hline
\end{tabular}

The levels of managment : Thelevelsof management referstoalineofdemarcationbetweenvariousmanagerialpositionsinanorganisation.

Thenumberoflevelsinmanagementincreaseswhenthesizeofthebusinessandworkforceincreasesandviceversa.

Thelevelofmanagement determines a chain of command, the amount of authority and status enjoyed by any managerial position.

The levels of management can be classified into three broad categories- Top level/Administrative level, Middle level/Executory and Lower level/Supervisory/Operative/First-line managers.

The SOEs'organisationalstructure shows traces of the existence of the various levels of management. The organisational chart has been prepared by all, however, there are some line of authority and work definition that overrules the outlined structure with no proper management level to be identifiable.

Table 2 shows the composition of the employees working in the five SOEs in Mizoram. MAMCO has the least number of employees (43 in number) and MIFCO has the maximum number of employees (103 in number). The outlined structure given in Table 3 is the classification that the SOEs follow which is based on grading by pay scale, an attempt is made in Table 3 to classify the personnel by the managerial levels to facilitate a better understanding of function and span of management.

Table 2:- Composition of personnel in the SOEs: groupwise.

\begin{tabular}{|l|c|c|c|c|c|}
\hline Particulars & ZIDCO & ZOHANDCO & MIFCO & ZENICS & MAMCO \\
\hline Group A & 8 & 5 & 12 & 4 & 3 \\
\hline Group B & 26 & 9 & 11 & 3 & 3 \\
\hline Group C & 36 & 20 & 48 & 6 & 11 \\
\hline Group D & 11 & 16 & 20 & 14 & 9 \\
\hline Muster Roll & - & 21 & 12 & 3 & 17 \\
\hline
\end{tabular}




\begin{tabular}{|l|l|l|l|l|l|}
\hline Total & 81 & 71 & 103 & 45 & 43 \\
\hline
\end{tabular}

Table 3:- Composition of personnel by managerial level in the SOEs.

\begin{tabular}{|l|l|l|l|l|l|}
\hline Particulars & ZIDCO & ZOHANDCO & MIFCO & ZENICS & MAMCO \\
\hline Board of Directors & 11 & 9 & 12 & 9 & 10 \\
\hline Managerial-TopLevel & 1 & $1^{*}$ & 1 & $1 *$ & $1^{*}$ \\
\hline Managerial-MiddleLevel & 5 & $1+1$ & 3 & 4 & 3 \\
\hline Managerial-Supervisory Level & 9 & $4+3$ & 7 & 4 & 2 \\
\hline Non-managerial- Regular & 55 & $25+16$ & 80 & 34 & 21 \\
\hline Non-managerial-Muster Roll & 11 & $16+5$ & 12 & 3 & 17 \\
\hline Total & $\mathbf{8 1}$ & $\mathbf{7 1 \#}$ & $\mathbf{1 0 3}^{* *}$ & $\mathbf{4 5}$ & $\mathbf{4 3}$ \\
\hline
\end{tabular}

Notes:

The Managing Directors of ZOHANDCO, ZENICS and MAMCO are from the administrative departments and are managing the companies on part-time basis.

The organisation is divided into two distinctive parts, the employees of the corporation forms 30 of the workforce and the other 20 are employees under Tribal Handloom Development Project which was a project initiated with the help of the Development Commissioner, Handlooms, Ministry of Textiles, Government of India. The project carried on 1992-2001, the employees have been retained by the Government of Mizoram since then.

MIFCO has highest number of employees, it may be due to the fact that it is a manufacturing organisation with a number of branches spread across the state. However, the public as well as the organisation have stated that they are overcrowded, as 38 employees were transferred from the Industries Department at the beginning of the corporation'slifewithoutexpandingtheworkcapacity. Thisresultedinexcessivedraininthetreasury due to heavy administrative expenses. The members of the Board of Directors are not under the employment of the corporation but they form a very important part of the management as they act as the policy makers, therefore a mention has been made in the table.

The service period of the Board of Directors and the chairman in particular has received criticism from experts, not only in Mizoram but in other parts of the country by public enterprise researchers and experts. The tenure ship sometimes is less than a year and the enterprise seems to have as many chairmen as their years of existence. For example, ZOHANDCO had had 10 chairmen and 15 managing directors in its 20 years of existence. Good management practice says that at least a five year corporate plan should be made which means that the chairman and managing directors, not to mention the members of the board have never once stayed long enough to see their plans realised.

\section{Departmentation:}

A fundamental characteristic of organisation structure is departmentation, which is the basis for grouping positions into departments and departments into the total organisation (Daft, 2009). The term departmentation used in a generic sense is not only confined to the creation of such units as are called departments, but it includes divisions, sections and jobs also. Dividing up work calls for identification of total activities and classification of such activities into units and subunits.

The enterprises are small in size and have been formed to cater to a particular category of needs. For instance, MAMCO is a trading enterprise dealing exclusively with agricultural products; ZENICS is involved with the electronics and information and communication technology; MIFCO deals with fruit processing; ZOHANDCO promotes and markets handlooms and handicrafts, and ZIDCO is a financial corporation. As such, the enterprises are departmentalised to accommodate their objectives. The administrative and finance departments are common to all, and there are specific departments peculiar to the nature and function of the organisation.

Table 4:- Patterns of departmentation in the SOEs.

\begin{tabular}{|l|c|c|c|c|c|}
\hline Departments & ZIDCO & ZOHANDCO & MIFCO & ZENICS & MAMCO \\
\hline 1. Administrative & $*$ & $*$ & $*$ & $*$ & $*$ \\
\hline 2. Finance \& Accounts & $*$ & $*$ & $*$ & $*$ & $*$ \\
\hline 3. Sales\& Marketing & & $*$ & $*$ & & $*$ \\
\hline
\end{tabular}




\begin{tabular}{|l|c|c|c|c|c|}
\hline 4. Production & & $*$ & $*$ & & \\
\hline 5. Projects & $*$ & & & & \\
\hline 6. Recovery & $*$ & & & & \\
\hline 7. Technical & & & & $*$ & \\
\hline 8. Legal \& Documentation & $*$ & & & & \\
\hline \multicolumn{1}{|c|}{ TOTAL } & $\mathbf{5}$ & $\mathbf{4}$ & $\mathbf{4}$ & $\mathbf{3}$ & $\mathbf{3}$ \\
\hline
\end{tabular}

Having the listed department.

Table 4. gives a view of the departmentation in SOEs in Mizoram. It is interesting that the corporations that are at the end of the list in terms of performance (ZOHANDCO, MIFCO and ZIDCO) are having four to five departments each and the two smaller (MAMCO and ZENICS) but better of the group are having three departments. An important principle of organising is simplification implying clear definition of roles and goals, this needs to be signified. The employees of these enterprises when asked to clarify their roles were often unable to do so in clear terms which could indicate confusion in job content and lack of proper instruction and supervision.

The MIFCO work system is based on projects and it has been given a sub unit within the department. The project department instead of occupying a permanent division could be established on a temporal need-based, enabling the staff to engage themselves in other work areas when project is completed. It has been noted that projects undertaken has given negative results continuously. In such situations, the management may gain by reorganising the departmentation structure.

The departmentation of ZIDCO is commendable as it has given priority to the recovery of loans by establishing it as a separate division. It has given projects a separate department, the project management of these enterprises have been tinted with controversies and failure to deliver on time.

On the other hand, ZENICS on its proposal for the restructuring of the company has attempted to restructure by increasing the departmentation into 6 divisions which are Establishment \& Administration, Finance \& Accounts, Sales \& Marketing, Production, E-governance and HRD. This is a partial departmentation by function and by product. It points toward a high degree of specialisation which may very well benefit the organisation provided there is proper delegation of authority.

Span of Management:

Span of control or span of management is a dimension of organisational design measured by the number of subordinates that report directly to a given manager. The trend in recent years has been to move toward a wider span of control to reduce costs, speed decision making, increase flexibility and empower employees. However, to avoid potential problems of wide span of control, organisations are having to invest in training managers and employees and in technology enabling the sharing of information and enhancing communication between and among managers and employees.These factors gives a convincing argument for a wider span of control but at the same time stressing on the importance of the given situation to decide on a wider or narrower span of control. Gone are the days when management theorists specify the number of subordinates that a manager can handle effectively. The emphasis is on the situational approach.

The enterprises'organisationalchartisnarrowatthetopandwideatthelowerlevel. Infact,MIFCOhasaveryunproportionate bottom pyramid with the Managing Director at the top level with three deputy managers under him and the three managers having seven assistant managers which is a very narrow span of control, these executives then have 92 non-managerial workers to manage which is quite inconsistent with the top level.

The pattern is more or less the same for the other enterprises as they all have a very narrow span of management which as explained is expensive, slow, rigid, demotivating and complicated. ZIDCO has the top-middle-supervisory level at 1-5-9; ZOHANDCO has 1-2-7; MIFCO has 1-3-7; ZENICS has 1-4-4 and MAMCO has 1-3-2. The narrow span is of course, not ruled out as there are circumstances where the work is complex and this will necessitate a narrower span. However, the corporations have the same narrow span of management ever since their inception. Perhaps, the corporations would benefit more if they had a wider span of control as the size, nature and type of operation do not necessitate a narrow span of control.

The adoption of narrow span can perhaps be regarded as an ill attempt to replicate the government administrative department which may require the narrow span as the nature and purpose differ to a great extent with enterprises. 
In fact, the ZENICS' restructuring plan has proposed a 1-6 division which gives a direct line of authority with the managing director to all the heads of the division or departments. This gives the managers of each division a clear uninterrupted access to report and delegate, the present structure has some of the proposed division working as subdivision butare quite independent of each other in terms of activities, which can hamper the possibilities of taking advantage of specialisation at the optimal level. The line of reasoning however, is not narrow span vs. wider span of management. The principle of the span of management is that there is a limit to the number of subordinates a manager can effectively supervise, and the exact number will depend on various factors that is distinctive in each situation within each organisation. What is required is more precise balancing, in a given situation, of all pertinent factors. Widening spans and reducing the number of levels may be the answer in some cases, the reverse may be true in others. One must balance the costs and benefits of adopting one course or the other, in terms of financial and non- financial costs.

\section{Delegation of Authority:}

Delegation is the authorisation of a manager to act in a certain way independently. The process of delegation of authority in the SOEs is largely centralised by the Board of Directors as the governing body in all of the enterprises. The Memorandum of Association and Articles of Association of the corporations confer the powers and duties of the Board of Directors to make bye laws; increase of share capital; appointment of all officers; to hold a meeting at least once in every three calendar months; inspection of accounts of the company during business hours; winding up of the company; to sell, dispose of, let on lease or on hire or transfer the business property, etc.; to appoint auditors; to accept profit \& loss accounts prepared by the auditor; to accept the shares or debentures, mortgage debentures or other security of any other company, etc.

The managing director is entrusted and conferred the powers excerciseable under the Articles of Association by the Board to manage the affairs of the company. The authority is delegated to the middle level and the supervisory level for the accomplishment of their assigned duties by the managing director.

Most failures in effective delegation occurs not because managers do not understand the nature and principles of delegation but because they are unable or unwilling to apply them. Much of the reason lies in manager's attitudes toward delegation. An underlying attribute of managers who will delegate authority is a willingness to give other people's ideas a chance. A manager who is effective in delegating authority must be willing to release the right to make decisions to subordinates. Thus, the SOEs' ability to effectively delegate is directly dependant upon the managing director's personal attitude. He is the sole authority, as far as the company affairs are concerned, that has the right to delegate. And if the managing director is in favour of delegating authority, then the managers under him would then be able to delegate further. Delegation of authority is a powerful tool for managerial effectivity as the very nature of management is based on the fact that dynamism is brought forth by group efforts. A major failing of the SOEs is the failure to delegate authority in the proper manner that could ensure proper flow of work and accountability.

\section{Informal Organisation:}

The majority of the staff are Mizos, the Mizo people as a culture have a strong bonding custom that easily enables them to interact amongst peers and work-groups, this typically shows in the SOEs as well, which has its advantage as well as a disadvantage. The advantage is that a strong informal group is effortlessly formed which gives a moral and emotional support system to the workers of the SOEs, the disadvantage arises from the infectious spread of dissatisfaction and a general lack of belief in the state of affairs of the enterprises and distrust in the government as a whole. All the five SOEs have employee welfare associations to cater to their grievances and welfare needs. The enterprises are also informally associated with each other through a unified informal association named Mizoram Government Corporation Employees Federation (MIGCEF). The MIGCEF has been instrumental in presenting their grievances to the public and the concerned government through press releases and have conducted seminars in collaboration with academic institutions.

\section{Conclusion:-}

The scanning of the SOEs based on the managerial principles of organising leaves much room for improvement, the commercial undertakings of government often fall short due to the crucial mistake that it is managed as if it were an administrative department, while being expected to perform profitably and measured based on business principles. It often gives rise to the question of whether government should get involved in running profit-based organisations at all. 


\section{References:-}

1. Bhatia, B,S and Batra, G..S (ed.) (2000): Management Audit as a Service to Public Enterprise, in Public Enterprises Management, Deep and Deep Publication,New Delhi.

2. Daft, Richard L. (2009): Principle of Management, Cengage Learning, New Delhi.

3. Davis, Keith. (1983): Human Behaviour at Work - Organisational Behaviour; TataMcGraw-Hill Publishing Company Ltd., New Delhi.

4. Ganesh, Gopal (2010): State Level Public Sector Enterprises in India - Performance and Prospects, Bookwell, New Delhi.

5. Jones, Leroy P. (ed.)(1982): Public Enterprise in Less-Developed Countries, Cambridge University Press, New York.

6. Mishra, R.K. and Kiranmai, J. (2007): State Level Public Enterprises in Sikkim - Policy and Planning, Concept Publishing Company, New Delhi

7. Mishra, R.K; Kumari, Ch.Lakshmi; Navin, B and Geeta, P (2006); Economic Liberalisation and Public Enterprise, Concept Publishing Company, New Delhi

8. Mittal, A.C. (ed.) (1992): Public Sector Management: Some Aspects of Management, Omsons Publications, New Delhi.

9. Narain, Laxmi (1981): Organisation Structure in Large Public Enterprises ( Case Studies of Five Major Public Enterprises), Ajanta Publications, New Delhi.

10. Ramanadham, V.V. (1984): The Nature of Public Enterprise, Croom Helm, London \& Sydney.

11. Saraswathy Rao, Y. (1986): Public Enterprises (A state level perspective),B.R. Publishing, Delhi. 